\section{OPEN ACCESS}

Edited by:

Donald Sodora

Seattle Children's Research Institute,

United States

Reviewed by:

Nina Derby,

Population Council, United States

*Correspondence: Ander Mayor-Ibarguren andermayor@gmail.com

tThese authors have contributed equally to this work

Specialty section:

This article was submitted to

Viral Immunology,

a section of the journa

Frontiers in Immunology

Received: 08 April 2020

Accepted: 29 June 2020

Published: 10 July 2020

Citation:

Mayor-Ibarguren A,

Busca-Arenzana $C$ and

Robles-Marhuenda Á (2020) A Hypothesis for the Possible Role of Zinc in the Immunological Pathways

Related to COVID-19 Infection.

Front. Immunol. 11:1736.

doi: 10.3389/fimmu.2020.01736

\title{
A Hypothesis for the Possible Role of Zinc in the Immunological Pathways Related to COVID-19 Infection
}

\author{
Ander Mayor-lbarguren ${ }^{1 * \dagger}$, Carmen Busca-Arenzana ${ }^{2 \dagger}$ and Ángel Robles-Marhuenda ${ }^{2 \dagger}$ \\ ${ }^{1}$ Department of Dermatology, La Paz University Hospital, Madrid, Spain, ${ }^{2}$ Department of Internal Medicine, La Paz University \\ Hospital, Madrid, Spain
}

Keywords: COVID-19, SARS-CoV-2, treatment, zinc, IL-6

\section{KEY POINTS}

- Zinc deficiency may be common and associated with severe infection.

- Zinc helps to enhance the interferon type 1 response to the virus and participates in many regulatory pathways.

- Low levels of zinc have been associated with higher IL-6 responses.

- IL-6 plays an important role in severe lung injury due to COVID-19 infection.

- Zinc inhibits SARS-CoV RNA polymerase, and thus its replication capacity.

- Zinc may increase the efficacy of antimalarial agents, since they are zinc ionophores.

- Differences in mortality due to COVID-19 infection may be explained to some degree by-174 IL-6 gene polymorphism.

Zinc $(\mathrm{Zn})$ is the second most abundant trace metal in the human body after iron. However, unlike iron, there is no specialized zinc store (1). Zinc's functions can be classified as catalytic, structural, and regulatory (2). For example, important zinc metalloenzymes include alkaline phosphatase, RNA polymerases, and alcohol dehydrogenase (3). Zinc deficiency can precipitate an immune system imbalance, exemplified in severe deficiency by high susceptibility to infections, skin disorders, gastrointestinal disorders, weight loss, growth retardation and male hypogonadism, amongst other symptoms (4). While severe zinc deficiency is rare, mild to moderate deficiency is more common worldwide (5). There are very low levels of free zinc in plasma, since it is mostly bound to proteins such as albumin, alpha-2-macroglobulin (A2M), and transferrin. Plasma zinc levels are therefore only around $1 \mu \mathrm{g} / \mathrm{ml}$, equal to $0.1 \%$ of total body zinc, but are still the most important reservoir for zinc homeostasis, which requires "free" or "labile" zinc mobilization $(6,7)$. Kinetic studies suggest that only a small proportion of total body zinc $(10 \%)$ represents the "functional pool" of zinc, located within the liver and other tissues, that exchanges rapidly with that found in the plasma $(8,9)$. When this functional pool is depleted, zinc deficiency ensues (8). Intracellular zinc is distributed in zinc-storing vesicles called zincosomes, the nucleus and other organelles. In cytoplasm, zinc mostly binds zinc-chelating proteins called metallothioneins (MTs). Zinc homeostasis is understood to be the correct balance of zinc distribution. Internal zinc homeostasis is regulated by the cooperative activities of two metal transporter protein families. One family consists of 10 solute-linked carrier 30 (SLC30 or ZnT) exporters, and the other family consists of 14 solute-linked carrier 39 (SLC39 or ZIP) importers (10, 11). For instance, most labile zinc in the body is absorbed by intestinal epithelial cells via SLC39a4 protein, and excessive zinc is excreted through the kidneys, and the intestine via SLC39a5 (12). 
We are currently experiencing an unprecedented COVID-19 pandemic caused by a novel RNA coronavirus called SARS-CoV2 , which can produce a severe acute respiratory distress syndrome (ARDS) (13). It was first detected in Wuhan province in China at the end of 2019 (14), and on 11 March 2020, WHO characterized COVID-19 as a pandemic (15). The reported mortality rate for those infected varies between countries (0.5-7.7\%) with the most important focus previously in Italy and Spain and currently in the USA, UK, and Brazil (16-19). Age, male sex, and pre-existing chronic metabolic diseases including diabetes, cardiovascular disease, and obesity are associated with greater severity of infection (20). There is no specific treatment yet. Many agents are being used with variable success, but none have had their efficacy demonstrated in clinical trials. Examples include: antimalarial agents such as chloroquine and hydroxychloroquine, antivirals such as lopinavir/ritonavir and remdesivir, and tocilizumab as an anti-interleukin 6 (IL-6) receptor antibody (21-24). Remdesivir has shown good initial clinical outcomes in a clinical trial, when treatment started within 10 days of symptom onset (25). In contrast, in a double-blind randomized trial of 237 patients with severe COVID-19 (hypoxia and radiographically confirmed pneumonia) in China, time to clinical improvement was not statistically different with remdesivir compared with placebo taken for 10 days (median time to improvement 21 vs. 23 days; hazard ratio for improvement 1.23 [95\% CI $0.87-1.75]$ ] (26). Mixed and controversial results have also been published regarding antimalarial agents (27). Thus, more robust data are needed before conclusions can be drawn regarding treatment. IL-1 and IL-6 may play an important role in severe lung inflammation, leading to acute respiratory distress syndrome, which can result in patient death $(28,29)$. This pathway appeared relevant in SARS-CoV, producing severe acute respiratory syndrome (SARS), and in MERS-CoV, producing Middle East respiratory syndrome (MERS) (30). High serum levels of proinflammatory cytokines [IL-1, IL-6, IL-12, interferon $\gamma$ (IFN$\gamma$ ), and transforming growth factor- $\beta$ ] and chemokines (CCL2, CXCL9, CXCL10, and IL-8) were found in patients with SARS with severe disease compared with individuals with uncomplicated SARS (31). MERS-CoV infections of dendritic cells and macrophages result in robust and sustained production of pro-inflammatory cytokines and chemokines such as TNF$\alpha$, IL-6, CXCL-10, CCL-2, CCL-3, CCL-5, and IL-8 (32). The purpose of this article is to highlight the key roles that zinc can play in COVID-19 infection (summarized in Figure 1), based on pre-existing evidence of its role in immune system function and viral infections, as well as its estimated possible deficiency in at-risk populations.

Zinc deficiency may be present in up to $17 \%$ of the population worldwide. The elderly especially are at higher risk of zinc deficiency and its adverse effects (33). Impairment of zinc homeostasis has also been demonstrated in metabolic diseases including diabetes, obesity, and cardiovascular disease (34). Many antihypertensive drugs such as ACE inhibitors, angiotensin 2 receptor antagonists, and thiazide diuretics are zinc chelators (35). Iron and calcium may interfere with zinc absorption too (36). The US Food and Nutrition Board recommends intake of 11 and $8 \mathrm{mg} /$ day for adult men and women, respectively
(37). Apart from calcium and iron, non-digestible plant ligands such as phytate, some dietary fibers, and lignin chelate zinc and inhibit its absorption. Measurement of plasma zinc levels is the most useful clinical test for zinc deficiency, despite limited sensitivity, and specificity (38). Also, plasma zinc levels remain stable even with low dietary intake, due to homeostasis in the body, decreasing in blood only when deficiency is very prolonged (39). The absence of a dedicated store for zinc repletion results in impairment of function when zinc status is compromised. Homeostasis maintains a constant intracellular zinc concentration and a plasma concentration within the reference range of $11-25 \mu \mathrm{M}(0.7-1.6 \mathrm{mg} / \mathrm{L})(40)$. Low plasma zinc has been defined as $<60 \mathrm{mcg} / \mathrm{dL}(<9.2 \mu \mathrm{M})$ (41). When zinc intake decreases, homeostatic mechanisms initially maintain the plasma concentration within the reference range, but when deficiency is severe or prolonged, the concentration decreases. However, although plasma zinc concentration moderately correlates to habitual intake, the test also has limited specificity because zinc levels are depressed during inflammatory disease states or pregnancy and increase with acute catabolic states (42). In mild diseases, with C-reactive protein (CRP) levels of $15 \mathrm{mg} / \mathrm{L}$, a $10 \%$ decrease in zinc is observed. In severe infectious diseases, CRP levels can reach 100-200 mg/L, with a much greater decrease in zinc levels (40-60\%) (43). If CRP levels are normal, plasma zinc measurements are more reliable. Moreover, the test has limited sensitivity since patients with mild zinc deficiency may have normal plasma levels (44). The copper:zinc ratio may be an interesting marker for the diagnosis of zinc deficiency, since the latter leads to an increase in copper absorption (45). To be reliable, this ratio must be higher than 1.5. However, critical patients may have high levels of copper, reflecting the effects of the systemic inflammatory response, thus not reliably representing their actual levels (46). A marker that might be more sensitive to the nutritional status of zinc is the ratio of Apo/Holo activities of angiotensin converting enzyme (47). Zinc levels may also be measured in neutrophils, lymphocytes, or erythrocytes, but these assays generally have poor sensitivity $(48,49)$. Ruz $\mathrm{M}$ et al. reported that zinc levels in neutrophils do not change, even in the event of changes in plasma concentrations during experimentally-controlled zinc depletion (48). Metfah et al. found that zinc levels in lymphocytes, granulocytes, and platelets decreased significantly only during the late zinc depletion phase (49). Interestingly, plasma zinc levels did not change even during the late zinc depletion phase in this study. In contrast, they found that activity of ecto-5' -nucleotidase (an integral zinc-dependent plasma enzyme located on most mammalian cells) was significantly decreased during mild zinc deficiency. When measured in neutrophils, zinc deficiency is defined as $<42 \mathrm{mcg} / 10^{10}$ cells ( 49 ). When measured in lymphocytes, zinc deficiency is defined as $<50 \mathrm{mcg} / 10^{10}$ cells (49). Taking all this into account, we highlight that there is no good reliable definition for zinc deficiency, besides a low plasma concentration with respect to normal reference levels, which may not be representative, especially in acute states or mild grades.

Zinc homeostasis in immune system pathways is complex, since it participates both in pro-inflammatory and regulatory pathways, and much of the data comes from preclinical in 


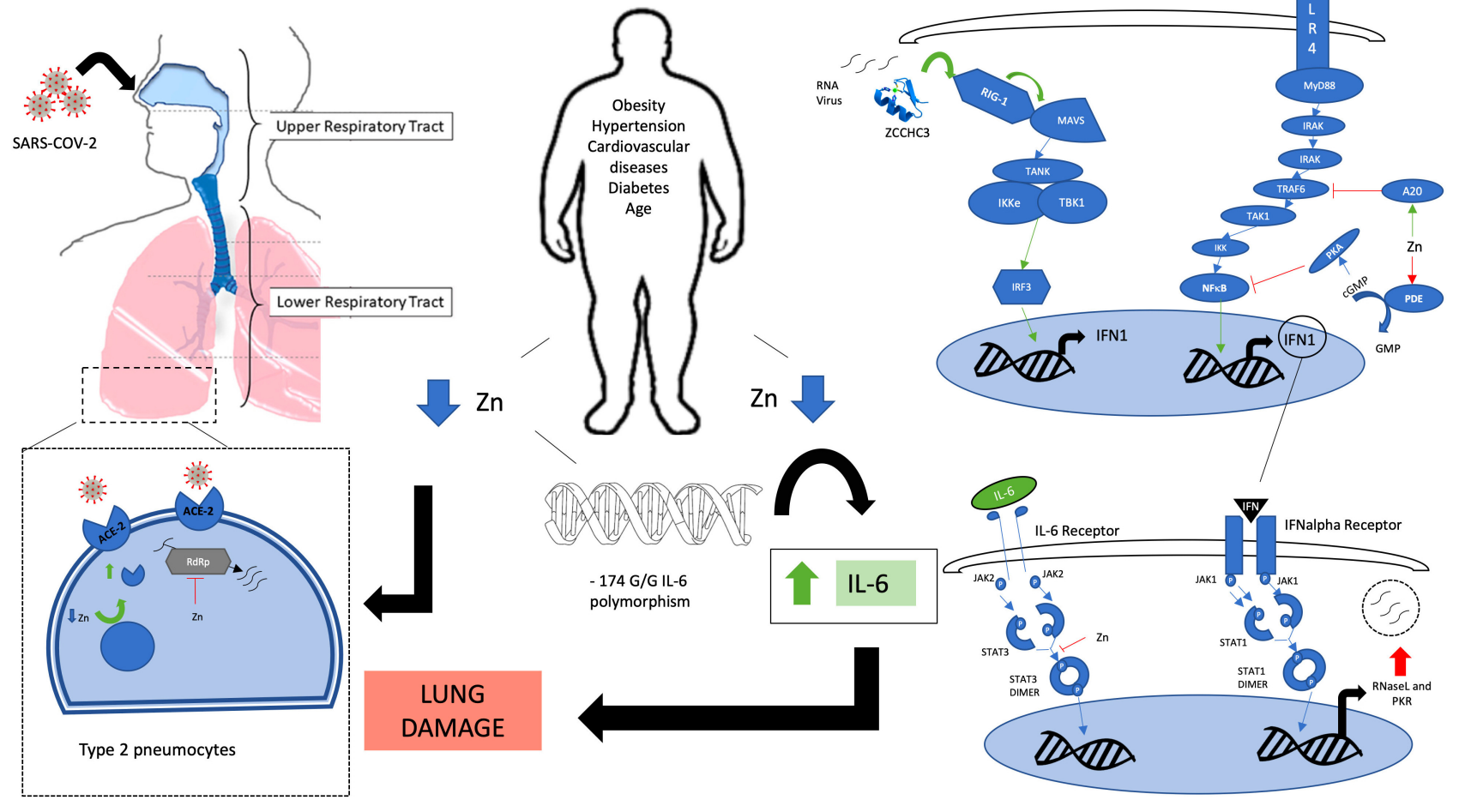

FIGURE 1 | Legend: A schematic view of the involvement of zinc in various signaling pathways. Green arrows: zinc-mediated activation. Red T bar arrows: zinc-mediated inhibition. Blue arrows: Flow of activation pathway. Obesity, cardiovascular disease, diabetes, and aging are associated with zinc deficiency. -174 GG polymorphism on the IL-6 promoter gene is associated with zinc homeostasis impairment and elevated IL-6 levels which contribute to lung damage. Zinc deficiency may increase ACE-2 receptor activity on type 2 pneumocytes and other cells that are infected by SARS-COV-2, mainly in the lower respiratory tract. Zinc inhibits RdRP, blocking viral RNA replication. Zinc-finger protein ZCCHC3 senses viral RNA and activates through RIG-1-like receptor a cascade that results in an increase in the interferon type 1 response. IFN type 1 stimulates synthesis of antiviral proteins such as RNaseL and PKR. Zinc helps to regulate the same kind of responses by activating the A20 protein that inhibits TRAF6 downstream activation, and by inhibiting PDE, which results in increased levels of cGMP that will activate PKA that will inhibit NF-кB. Zinc also inhibits STAT-3 dimerization, blocking active STAT3 signaling from the IL-6 receptor. Acronyms: ZCCHC3: Zinc finger CCHC domain-containing protein 3. RIG-1, retinoic acid-inducible gene I; MAVS, Mitochondrial antiviral-signaling protein; TANK, TRAF family member-associated NF-KB activator; Iкkع, I kappa B kinase epsilon; TBK1, TANK binding kinase 1; IRF3, interferon regulatory factor 3; TLR, Toll-like receptor; MyD88, myeloid differentiation primary-response protein 88; IRAK, interleukin-1 receptor-associated kinase; TRAF-6, tumor necrosis factor receptor-associated factor 6; TAK1: IKK, I kappa B kinase; NFKB, nuclear factor kappa B; A20, zinc protein; PDE, phosphodiesterase; cGMP, cyclic guanosine-monophosphate; GMP, guanosine-monophosphate; PKA, protein kinase A; INF-1, interferon type 1; JAK, janus kinase; STAT, signal transducer and activator of transcription; RNase L, Ribonuclease L; PKR, RNA-activated protein kinase; ACE-2, angiotensin-converting enzyme 2; RdRp, RNA-dependent RNA polymerase.

vitro studies. Despite this, it seems clear that deficient or excessive zinc levels can lead to malfunction of the adaptive and innate immune systems. Zinc regulates the proliferation, differentiation, maturation and functioning of lymphocytes, and other leukocytes (6). It also regulates the immune response, and its deficiency increases susceptibility to inflammatory and infectious diseases, including pneumonia (50). Zinc sulfate supplementation at $20 \mathrm{mg}$ /day for 5 months reduced acute lower respiratory tract infection morbidity vs. placebo in a clinical trial (51). Zinc is essential in both the adaptive and innate immune systems (52). For instance, the functionality of natural killer (NK) cells, which are essential for maintaining the immune response against viruses and tumors, is affected by low levels of zinc (53). Furthermore, zinc supplementation significantly increased NK cell numbers in whole blood cultures and NK cell activity in vivo $(54,55)$. In this latter study, zinc supplementation in subjects with low or borderline-normal circulating zinc increased the concentration of this ion and improved NK lytic activity, as well as modulating plasma IL-6. Zinc homeostasis directly influences the formation of lymphocytes and the secretion of cytokines and indirectly alters their stimulation by the innate immune system (56). There is also evidence that unregulated zinc homeostasis in macrophages impairs phagocytosis and results in an abnormal inflammatory response (57). In a study performed in mice, a diet deficient in zinc was associated with more pronounced airway inflammation after agricultural organic dust exposure, compared with normal dietary zinc intake (58). This was partially explained by the fact that macrophages maintained in a zinc-deficient environment exhibited increased CXCL1 and Il-23 production, as a result of increased NF-kB activation. Also, pulmonary zinc deficiency may be one of the mechanisms by which HIV-1 infection impairs alveolar macrophage immune 
function and facilitates severe pulmonary infection in these individuals (59).

Zinc also has a role in viral recognition. The zinc-finger protein ZCCHC3 binds RNA and facilitates the detection of intracellular RNA viruses by activating retinoic acid-inducible gene-I (RIG-1)-like receptors (RLRs), including RIG-I and MDA5 (60). This action triggers the activation of the antiviral response mediated by downstream activation of antiviral genes (61). In this process, kinases such as TBK1 and IкK further phosphorylate the interferon regulatory transcription

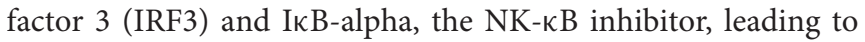
activation of IRF3 and NF- $\kappa$, which results in interferon type 1 upregulation $(62,63)$ (see Figure 1). Interferon alpha-induced signaling results in upregulation of antiviral proteins (RNase L and PKR), known to degrade viral RNA and inhibit its translation (64). Zinc also exerts an inhibitory effect on the activation of $\mathrm{NF}-\kappa \mathrm{B}$, through the expression of the A20 protein. A20 is a zinc-finger protein that negatively regulates tumor necrosis factor receptor (TNFR) and toll-like receptor (TLR)-initiated NF-kB pathways (65). Furthermore, zinc acts as an inhibitor of cyclic nucleotide phosphodiesterase (PDE). When PDE is inhibited, cyclic nucleotide cGMP (cyclic guanosine monophosphate) is elevated, leading to the activation of PKA (protein kinase A), and subsequent inhibition of NF-кB (66). Additionally, zinc supplementation has been shown to downregulate inflammatory cytokines by decreasing gene expression of IL-1 $\beta$, TNF-alpha, and by inhibiting NF- $\mathrm{KB}$ activation (67).

Nutritional immunity is a process by which the host organism sequesters trace minerals during an infection so that their availability to pathogens is limited (1). During infection and inflammation, there is a transient transfer of zinc from serum to the organs, causing temporarily low serum zinc levels, which normalize during resolution of the inflammatory response $(6,7)$. Thus, a sufficient level of zinc is essential during responses to infection. Zinc signals act in an anti-inflammatory manner during sepsis by regulating the pro-inflammatory response, due to cellular uptake of zinc by ZIP14 as shown in a polymicrobial model of sepsis in mice (68). Zinc deficiency was strongly associated with an elevated risk of exaggerated inflammation and mortality due to sepsis in a murine model (69). In this study, mice with a zinc-deficient diet had a $50 \%$ reduction in plasma zinc levels compared with those with a normal diet, and had a significantly lower survival rate of $10 \%$ in the context of sepsis. Based on the studies mentioned above, one could hypothesize that an initial chelation of zinc would trigger an antiviral response mediated by interferon type 1 (IFN-I). However, ensuring an adequate level of zinc would be necessary to regulate this response, since zinc participates as an inhibitory agent at many points in this pathway (see Figure 1). Indeed, an early IFNI response was shown to be optimal, while a delayed IFN-I response was associated with ARDS in a study with SARS-CoVinfected mice (70). IFN-1 subtypes were studied alone and in combination with other antiviral drugs for the treatment of SARS and MERS, in vitro and in vivo, with some beneficial reports, but later failed to improve outcomes in humans (71-73). Despite this, SARS-CoV-2 appears to be more sensitive than MERS or SARS-CoV to IFN type 1, and its use as prophylaxis or treatment is also being studied (74). Although it is also hypothesized that it should be tested on the early phase of infection, late phase anti-IFN type 1 treatment could be beneficial for treating severe disease (75). There is some evidence that SARS-CoV-2 infection triggers expression of numerous IFN-stimulated genes, which is thought to induce inadequate IFN responses (76). Although there are no specific data regarding zinc in this pathway for SARS-CoV-2, zinc may limit infection through upregulation of IFN-alpha production and an increase in its antiviral activity $(77,78)$. In this latter in vitro study, when cultures of white blood cells from elderly subjects were supplemented with $15 \mu \mathrm{M}$ zinc (the physiological concentration), they produced IFN in amounts comparable to those from the younger subjects. We hypothesize that transient zinc deficiency during infection could result in a hyperinflammatory state in those with prior zinc deficiency. Also, zinc deficiency has been linked to a loss of taste and smell, symptoms recently attributed to infection by this virus $(79,80)$. In our opinion, this could be a consequence of a transient acute zinc deficiency produced during infection. Zinc deficiency may diminish protein synthesis in taste bud cells, reduce alkaline phosphatase activity in taste buds, alter a zinc-containing salivary protein, block the taste pore region of the taste bud or lead to central nervous system dysfunction (81).

IL-6 appears to be important in triggering severe lung damage during SARS-CoV-2 infection. Sustained elevation of IL-6 is postulated as being responsible for severe immune-mediated lung damage as well as for macrophage activation syndrome (MAS) that might overlap in patients with severe COVID-19 (82). There is much evidence for how this cytokine storm may be related to zinc levels. Firstly, IL-6 induces expression of metallothioneins (MT) and alpha-2-macroglobulin (A2M) (both zinc-binding proteins), which can reduce zinc bioavailability. IL-6, MT, and A2M increase with age and impaired zinc availability contributes to immunosenescence (83). Secondly, zinc acts as an anti-inflammatory element, downregulating many pro-inflammatory signaling pathways, such as IL-6-mediated activation of STAT-3 (84). Thirdly, IL-6 production seems to be increased in zinc-deficient elderly subjects. Furthermore, obese patients with lower dietary intake of zinc present with lower plasma and intracellular zinc levels, along with upregulated gene expression of IL-1 alpha, IL-1 beta, and IL-6, compared with patients with higher zinc intake (85). In this in vivo study, $10 \mathrm{mg}$ of pure zinc supplementation resulted in a significant 96.5\% decrease in IL-6 release from white blood cells in healthy elderly subjects. Fourthly, a polymorphism has been described in the IL- 6 gene that is related to impaired zinc homeostasis. An IL-6 promoter gene single nucleotide polymorphism (SNP) at position -174 has been studied in several age-related diseases, such as cardiovascular disease, Alzheimer's disease, diabetes, and cancer (86-88). Zinc deficiency induces a progressive demethylation of the IL-6 promoter in THP1 cells, which correlated to increased IL-6 expression (89). Genetic variation at the IL-6-174G/C locus is involved in determining IL-6 production and the immune response. Elderly subjects with GG genotypes (called C-) have more risk of developing atherosclerosis due to higher IL-6 production, impaired K cell cytotoxicity, increased MT gene expression, and low zinc ion 
availability compared with C+ carriers (90). For instance, in elderly individuals aged $65-85$ years, $\mathrm{C}+$ polymorphism was associated with IL-6 levels of $0.88 \mathrm{pg} / \mathrm{ml}$ and zinc levels of $82.2 \mu \mathrm{g} / \mathrm{dl}$, whereas C- polymorphism was associated with IL6 levels of $1.21 \mathrm{pg} / \mathrm{ml}$ and plasma zinc of $77.5 \mu \mathrm{g} / \mathrm{dl}$, these differences being statistically significant. In another study, C+ carriers had significantly higher plasma zinc levels, lower MT production, higher red blood cell zinc levels, and good NK cell cytotoxicity, as shown in an in vivo study performed in elderly subjects (91). Thus, patients with IL-6-174 GG polymorphism (C-carriers) may be susceptible to developing a severe infection due to SARS-CoV-2, leading to an increase in IL-6 levels that produce a cytokine storm related to impaired zinc homeostasis. Interestingly, this polymorphism seems to be twice as common in people from Italy (68.1\%) and other Mediterranean countries, compared with northern European countries such as Germany (33.8\%) (91). This might explain, to some degree, the difference in mortality rates observed between these countries; as of the 21 March, Italy recorded 53,578 confirmed cases and 4,825 deaths, while Germany had 22,213 cases and 84 deaths (92). To date, Germany has one of the lowest case fatality rates at $4.10 \%$ as of the beginning of May, compared with Italy (13.61\%). It is probable that other factors, such as differences in early identification of cases and correct isolation, and differences in the proportion of the population that is elderly, may also have been important. Nevertheless, studies on genetic susceptibility for developing COVID-19 pneumonia and severe illness are underway $(93,94)$. There are no data regarding the prevalence of this polymorphism in other countries such as the UK or USA, which are known foci of the pandemic. The USA has almost 1,500,000 infected cases with more than 86,000 deaths, which translates to a fatality rate of $5.7 \%$ (92).

Zinc has shown its ability to inhibit SAR-CoV RNA polymerase (95). $\mathrm{Zn}^{2+}$ cations, especially in combination with Zn ionophore pyrithione, inhibited SARS-CoV RNA-dependent RNA polymerase, RdRP. A more than $50 \%$ reduction in overall RNA synthesis was observed at zinc levels of $50 \mu \mathrm{M}$, while $<5 \%$ activity remained at zinc levels of $500 \mu \mathrm{M}$. This finding would make zinc a potential antiviral agent for coronavirus diseases. Additionally, chloroquine and hydroxychloroquine, among their

\section{REFERENCES}

1. Gammoh NZ, Rink L. Zinc in infection and inflammation. Nutrients. (2017) 9:624. doi: 10.3390/nu9060624

2. Cousins RJ. Metal elements and gene expression. Annu Rev Nutr. (1994) 14:449-69. doi: 10.1146/annurev.nu.14.070194.002313

3. Maverakis E, Fung MA, Lynch PJ, Draznin M, Michael DJ, Ruben B, et al. Acrodermatitis enteropathica and an overview of zinc metabolism. J Am Acad Dermatol. (2007) 56:116-24. doi: 10.1016/j.jaad.2006.08.015

4. Prasad AS. Discovery of human zinc deficiency: its impact on human health and disease. Adv Nutr. (2013) 4:176-90. doi: 10.3945/an.112.003210

5. Sandstead HH. Zinc deficiency. A public health problem? Am J Dis Child. (1991) 145:853-9. doi: 10.1001/archpedi.1991.02160080029016

6. Wessels I, Maywald M, Rink L. Zinc as a gatekeeper of immune function. Nutrients. (2017) 9:1286. doi: 10.3390/nu9121286

7. Maywald M, Wessels I, Rink L. Zinc signals and immunity. Int J Mol Sci. (2017) 18:2222. doi: 10.3390/ijms18102222 other specific mechanisms, act as zinc ionophores and promote cellular uptake of zinc-a mechanism which may increase the effectiveness of these compounds in inhibiting the replicative capacity of the virus $(96,97)$. SARS-CoV-2 and SARS-CoV require angiotensin-converting enzyme 2 (ACE2) for entry into target cells. Zinc exposure reduced recombinant human ACE2 activity in rat lung (98). ACE-2 is a zinc metallopeptidase that contains a HEXXH motif that functions as the zincbinding domain at its active site. In this in vitro study, in the presence of $100 \mu \mathrm{M}$ zinc, activity was significantly $(p<0.05)$ decreased in rat lung and rhACE- 2 compared with 0 or $10 \mu \mathrm{M}$ zinc. In the presence of $1,000 \mu \mathrm{M}$ zinc, activity was further reduced $(p<0.05)$ in all three preparations compared with 0,10 , and $100 \mu \mathrm{M}$ zinc. Thus, hypothetically, zinc deficiency could facilitate SARS-CoV-2 infection of target cells due to an increase in ACE-2 activity that could facilitate binding with SARS-CoV-2.

In conclusion, the world is facing a pandemic caused by a novel coronavirus, with some countries suffering a higher burden of disease. The infection is known to more severely affect older people with various chronic comorbidities such as obesity, hypertension, and diabetes. Zinc has a known role in the regulation of immunity. A plausible biological mechanism for the involvement of zinc in this condition exists, which we summarize in Figure 1. Its supplementation, alone or as an adjuvant to medicines that are currently being used to treat active infection, could be beneficial due to its effect on many key factors in the regulation of a severe immune response during infection. Zinc supplementation could be a novel treatment for people at high risk of zinc deficiency who develop severe pneumonia due to Covid-19. We believe there is enough evidence to further investigate how zinc status or homeostasis is involved in the pathogenesis of severe illness produced by SARS-CoV-2 infection, and its potential role as an active treatment should be assessed in clinical trials.

\section{AUTHOR CONTRIBUTIONS}

All authors listed have made a substantial, direct and intellectual contribution to the work, and approved it for publication.
8. King JC. Assessment of zinc status. J Nutr. (1990) 120(Suppl. 11):14749. doi: 10.1093/jn/120.suppl_11.1474

9. Miller LV, Hambidge KM, Naake VL, Hong Z, Westcott JL, Fennessey PV. Size of the zinc pools that exchange rapidly with plasma zinc in humans: alternative techniques for measuring and relation to dietary zinc intake. J Nutr. (1994) 124:268-76. doi: 10.1093/jn/124.2.268

10. Huang L, Tepaamorndech S. The SLC30 family of zinc transporters - a review of current understanding of their biological and pathophysiological roles. Mol Aspects Med. (2013) 34:548-60. doi: 10.1016/j.mam.2012. 05.008

11. Jeong J, Eide DJ. The SLC39 family of zinc transporters. Mol Aspects Med. (2013) 34:612-9. doi: 10.1016/j.mam.2012.05.011

12. Geiser J, De Lisle RC, Andrews GK. The zinc transporter Zip5 (Slc39a5) regulates intestinal zinc excretion and protects the pancreas against zinc toxicity. PLoS ONE. (2013) 8:e82149. doi: 10.1371/journal.pone.0082149

13. Lai CC, Shih TP, Ko WC, Tang HJ, Hsueh PR. Severe acute respiratory syndrome coronavirus 2 (SARS-CoV-2) and coronavirus disease-2019 
(COVID-19): The epidemic and the challenges. Int J Antimicrob Agents. (2020) 55:105924. doi: 10.1016/j.ijantimicag.2020.105924

14. Gao Y, Yan L, Huang Y, Liu F, Zhao Y, Cao L, et al. Structure of the RNAdependent RNA polymerase from COVID-19 virus. Science. (2020) 368:77982. doi: $10.1126 /$ science.abb 7498

15. World Health Organization (WHO): Coronavirus Disease (COVID-2019). Situation Report- 81. Genevva: WHO (2020). (accessed April 10, 2020).

16. Legido-Quigley H, Mateos-García JT, Campos VR, Gea-Sánchez M, Muntaner C, McKee M. The resilience of the Spanish health system against the COVID-19 pandemic. Lancet Public Health. (2020) 5:e2512. doi: 10.1016/S2468-2667(20)30060-8

17. Lazzerini M, Putoto G. COVID-19 in Italy: momentous decisions and many uncertainties. Lancet Glob Health. (2020) 8:e641-2. doi: 10.1016/S2214-109X(20)30110-8

18. Gonzalez-Reiche AS, Hernandez MM, Sullivan MJ, Ciferri B, Alshammary H, Obla A, et al. Introductions and early spread of SARS-CoV-2 in the New York City area. Science. (2020) eabc1917. doi: 10.1126/science.abc1917

19. https://covid19.who.int (Accessed May 31, 2020).

20. Guan WJ, Ni ZY, Hu Y, Liang WH, Ou CQ, He JX, et al. Clinical characteristics of coronavirus disease 2019 in China. N Engl J Med. (2020). 382:170820. doi: $10.1101 / 2020.02 .06 .20020974$

21. Gautret P, Lagier JC, Parola P, Hoang VT, Meddeb L, Mailhe M, et al. Hydroxychloroquine and azithromycin as a treatment of COVID-19: results of an open-label non-randomized clinical trial. Int J Antimicrob Agents. (2020) 20:105949. doi: 10.1016/j.ijantimicag.2020.105949

22. Yao X, Ye F, Zhang M, Cui C, Huang B, Niu P, et al. In vitro antiviral activity and projection of optimized dosing design of hydroxychloroquine for the treatment of severe acute respiratory syndrome coronavirus 2 (SARS-CoV2). Clin Infect Dis. (2020) ciaa237. doi: 10.1093/cid/ciaa237. [Epub ahead of print].

23. Cao B, Wang Y, Wen D, Liu W, Wang J, Fan G, et al. A trial of lopinavirritonavir in adults hospitalized with severe Covid-19. N Engl J Med. (2020) 382:1787-99. doi: 10.1056/NEJMc2008043

24. Reuters. China Approves Use of Roche Drug in Battle Against Coronavirus Complications. Available online at: https://www.reuters.com/article/ushealth-coronavirus-china-roche-hldg/china- approves-use- of-rochearthritis-drug-for-coronavirus-patients-idUSKBN20R0LF (accessed March $11,2020)$.

25. https://www.niaid.nih.gov/news- events/nih-clinical-trial-shows-remdesiviraccelerates-recovery-advanced-covid- 19 (accessed April 29, 2020).

26. Wang Y, Zhang D, Du G, Du R, Zhao J, Jin Y, et al. Remdesivir in adults with severe COVID-19: a randomised, double-blind, placebo-controlled, multicentre trial. Lancet. (2020) 395:1569-78. doi: 10.1016/S0140-6736(20)31022-9

27. Meo SA, Klonoff DC, Akram J. Efficacy of chloroquine and hydroxychloroquine in the treatment of COVID-19. Eur Rev Med Pharmacol Sci. (2020) 24:4539-47. doi: 10.26355/eurrev_202004_ 21038

28. Conti P, Ronconi G, Caraffa A, Gallenga CE, Ross R, Frydas I, et al. Induction of pro-inflammatory cytokines (IL-1 and IL-6) and lung inflammation by Coronavirus-19 (COVI-19 or SARS-CoV-2): anti-inflammatory strategies. $J$ Biol Regul Homeost Agents. (2020) 34:1. doi: 10.23812/CONTI-E

29. Wang Z, Yang B, Li Q, Wen L, Zhang R. Clinical features of 69 cases with coronavirus disease 2019 in Wuhan, China. Clin Infect Dis. (2020) ciaa272. doi: $10.1093 / \mathrm{cid} / \mathrm{ciaa2} 272$.

30. Wang W, Ye L, Ye L, Li B, Gao B, Zeng Y, et al. Up-regulation of IL-6 and TNF-alpha induced by SARS-coronavirus spike protein in murine macrophages via NF-kappaB pathway. Virus Res. (2007) 128:18. doi: 10.1016/j.virusres.2007.02.007

31. Wong CK, Lam CW, Wu AK, Ip WK, Lee NL, Chan IH, et al. Plasma inflammatory cytokines and chemokines in severe acute respiratory syndrome. Clin Exp Immunol. (2004) 136:95-103. doi: 10.1111/j.1365-2249.2004.02415.x

32. Zhou J, Chu H, Li C, Wong BH, Cheng ZS, Poon VK, et al. Active replication of Middle East respiratory syndrome coronavirus and aberrant induction of inflammatory cytokines and chemokines in human macrophages: implications for pathogenesis. J Infect Dis. (2014) 209:133142. doi: $10.1093 /$ infdis/jit504
33. Yasuda H, Tsutsui T. Infants and elderlies are susceptible to zinc deficiency. Sci Rep. (2016) 6:21850. doi: 10.1038/srep21850

34. Olechnowicz J, Tinkov A, Skalny A, Suliburska J. Zinc status is associated with inflammation, oxidative stress, lipid, and glucose metabolism. J Physiol Sci. (2018) 68:19-31. doi: 10.1007/s12576-017-0571-7

35. Braun LA, Rosenfeldt F. Pharmaco-nutrient interactions - a systematic review of zinc and antihypertensive therapy. Int J Clin Pract. (2013) 67:71725. doi: 10.1111/ijcp.12040

36. Dursun N1, Aydogan S. Comparative effects of calcium deficiency and supplements on the intestinal absorption of zinc in rats. Jpn J Physiol. (1994) 44:157-66. doi: 10.2170/jjphysiol.44.157

37. Institute of Medicine: Dietary Reference Intakes for Vitamin A, Vitamin K, Arsenic, Boron, Chromium, Copper, Iodine, Iron, Manganese, Molybdenum, Nickel, Silicon, Vanadium, and Zinc. (2001). Available online at: https://www. nap.edu/catalog/10026/dietary-reference-intakes-for-vitamin-a-vitamin-karsenic-boron-chromium-copper-iodine-iron-manganese-molybdenumnickel-silicon-vanadium-and-zinc (accessed March 04, 2020)

38. Lowe NM, Fekete K, Decsi T. Methods of assessment of zinc status in humans: a systematic review. Am J Clin. (2009) 89:2040S-51S. doi: 10.3945/ajcn.2009.27230G

39. Livingstone C. Zinc: physiology, deficiency, and parenteral nutrition. Nutr Clin Pract. (2015) 30:371-82. doi: 10.1177/0884533615570376

40. Taylor A. Detection and monitoring of disorders of essential trace ele- ments. Ann Clin Biochem. (1996) 33:486-510. doi: 10.1177/000456329603300603

41. Hambidge KM, Casey CE, Krebs NF. Zinc. In: Mertz W, editor. Trace Elements in Human and Animal Nutrition. Orlando: Academic Press. (1986). p. 1. doi: 10.1016/B978-0-08-092469-4.50005-4

42. King JC, Cousins RJ. Zinc. In: Ross AC, Caballero B, Cousins RJ, Tucker KL, Ziegler TR, editors, Modern Nutrition in Health and Disease, $11^{\text {th }}$. Philadelphia, PA: Lippincott Williams and Wilkins. (2014). p. 189.

43. Galloway P, McMillan D, Sattar N. Effect of the inflammatory response on trace element and vitamin status. Ann Clin Biochem. (2000) 37:28997. doi: $10.1258 / 0004563001899429$

44. Wood RJ. Assessment of marginal zinc status in humans. J Nutr. (2000) 130:1350S. doi: 10.1093/jn/130.5.1350S

45. Yanagisawa H. Zinc deficiency and clinical practice. J Jap Med Assoc. (2004) 47:359-64. doi: 10.1248/yakushi.128.333

46. Stefanowicz F, Gashut RA, Talwar D, Duncan A, Beulshausen JF, McMillan DC, et al. Assessment of plasma and red cell trace element concentrations, disease severity, and outcome in patients with critical illness. J Crit Care. (2014) 29:214-8. doi: 10.1016/j.jcrc.2013.10.012

47. Takeda N, Takaoka T, Ueda C, Toda N, Kalubi B, Yamamoto S. Zinc deficiency in patients with idiopathic taste impairment with regard to angiotensin converting enzyme activity. Auris Nasus Larynx. (2004) 31:4258. doi: $10.1016 / \mathrm{S} 0385-8146(04) 00142-7$

48. Ruz M, Cavan KR, Bettger WJ, Gibson RS. Erythrocytes, erythrocyte membranes, neutrophils and platelets as biopsy materials for the assessment of zinc status in humans. Br J Nutr. (1992) 68:515-27. doi: 10.1079/BJN19920109

49. Meftah S, Prasad AS, Lee DY, Brewer GJ. Ecto 5' nucleotidase (5'NT) as a sensitive indicator of human zinc deficiency. J Lab Clin Med. (1991) 118:30916.

50. Haase H, Rink L. Multiple impacts of zinc on immune function. Metallomics. (2014) 6:1175-80. doi: 10.1039/c3mt00353a

51. Malik A, Taneja DK, Devasenapathy N, Rajeshwari K. Zinc supplementation for prevention of acute respiratory infections in infants: a randomized controlled trial. Indian Pediatr. (2014) 51:780-4. doi: 10.1007/s13312-014-0503-Z

52. Rink L, Gabriel P. Zinc and the immune system. Proc Nutr Soc. (2000) 59:541-52. doi: 10.1017/S0029665100000781

53. Allen JI, Perri RT, McClain CJ, Kay NE. Alterations in human natural killer cell activity and monocyte cytotoxicity induced by zinc deficiency. J Lab Clin Med. (1983) 102:577-89.

54. Metz $\mathrm{CH}$, Schröder AK, Overbeck S, Kahmann L, Plümäkers B, Rink L. T-helper type 1 cytokine release is enhanced by in vitro zinc supplementation due to increased natural killer cells. Nutrition. (2007) 23:157-63. doi: 10.1016/j.nut.2006.10.007

55. Mariani E, Neri S, Cattini L, Mocchegiani E, Malavolta M, Dedoussis GV, et al. Effect of zinc supplementation on plasma IL- 6 and MCP-1 production 
and NK cell function in healthy elderly: interactive influence of +647 MT1a and-174 IL-6 polymorphic alleles. Exp Gerontol. (2008) 43:46271. doi: 10.1016/j.exger.2007.12.003

56. Maares M, Haase H. Zinc and immunity: an essential interrelation. Arch Biochem Biophys. (2016) 611:58-65. doi: 10.1016/j.abb.2016.03.022

57. Gao H, Dai W, Zhao L, Min J, Wang F. The role of zinc and zinc homeostasis in macrophage function. I Immunol Res. (2018) 2018:6872621. doi: 10.1155/2018/6872621

58. Knoell DL, Smith DA, Sapkota M, Heires AJ, Hanson CK, Smith LM, et al. Insufficient zinc intake enhances lung inflammation in response to agricultural organic dust exposure. J Nutr Biochem. (2019) 70:5664. doi: 10.1016/j.jnutbio.2019.04.007

59. Joshi PC, Raynor R, Fan X, Guidot DM. HIV-1-transgene expression in rats decreases alveolar macrophage zinc levels and phagocytosis. Am J Respir Cell Mol Biol. (2008) 39:218-26. doi: 10.1165/rcmb.2007-0344OC

60. Lian H, Zang R, Wei J, Ye W, Hu MM, Chen YD, et al. The zincfinger protein ZCCHC3 binds RNA and facilitates viral RNA sensing and activation of the RIG-I-like receptors. Immunity. (2018) 49:43848.e5. doi: 10.1016/j.immuni.2018.08.014

61. Akira S, Uematsu S, Takeuchi O. Pathogen recognition and innate immunity. Cell. (2006) 124:783-801. doi: 10.1016/j.cell.2006.02.015

62. Lei CQ, Zhong B, Zhang Y, Zhang J, Wang S, Shu HB. Glycogen synthase kinase $3 \beta$ regulates IRF3 transcription factor-mediated antiviral response via activation of the kinase TBK1. Immunity. (2010) 33:87889. doi: 10.1016/j.immuni.2010.11.021

63. Mao AP, Li S, Zhong B, Li Y, Yan J, Li Q, et al. Virus-triggered ubiquitination of TRAF3/6 by cIAP $1 / 2$ is essential for induction of interferon-beta (IFN-beta) and cellular antiviral response. J Biol Chem. (2010) 285:94706. doi: 10.1074/jbc.M109.071043

64. Berg K, Bolt G, Andersen H, Owen TC. Zinc potentiates the antiviral action of human IFN-alpha tenfold. J Interferon Cytokine Res. (2001) 21:4714. doi: $10.1089 / 10799900152434330$

65. Haase H, Rink L. Functional significance of zinc-related signaling pathways in immune cells. Annu Rev Nutr. (2009) 29:133-52. doi: 10.1146/annurev-nutr-080508-141119

66. von Bülow V, Dubben S, Engelhardt G, Hebel S, Plümäkers B, Heine H, et al. Zinc-dependent suppression of TNF-alpha production is mediated by protein kinase A-induced inhibition of Raf-1, I kappa B kinase beta, and NF-kappa B. J Immunol. (2007) 179:4180-6. doi: 10.4049/jimmunol.179.6.4180

67. Prasad AS, Bao B, Beck FW, Kucuk O, Sarkar FH. Antioxidant effect of zinc in humans. Free Radic Biol Med. (2004) 37:118290. doi: 10.1016/j.freeradbiomed.2004.07.007

68. Wessels I, Cousins RJ. Zinc dyshomeostasis during polymicrobial sepsis in mice involves zinc transporter Zip14 and can be overcome by zinc supplementation. Am J Physiol Gastrointest Liver Physiol. (2015) 309:G76878. doi: 10.1152/ajpgi.00179.2015

69. Knoell DL, Julian MW, Bao S, Besecker B, Macre JE, Leikauf GD, et al. Zinc deficiency increases organ damage and mortality in a murine model of polymicrobial sepsis. Crit Care Med. (2009) 37:13808. doi: 10.1097/CCM.0b013e31819cefe4

70. Channappanavar R, Fehr AR, Vijay R, Mack M, Zhao J, Meyerholz DK, et al. Dysregulated Type I interferon and inflammatory monocytemacrophage responses cause lethal pneumonia in SARS-CoV-Infected mice. Version 2. Cell Host Microbe. (2016) 19:181-93. doi: 10.1016/j.chom.2016. 01.007

71. Stockman LJ, Bellamy R, Garner P. SARS: systematic review of treatment effects. PLoS Med. (2006) 3:1525-31. doi: 10.1371/journal.pmed.00 30343

72. Chan JF, Yao Y, Yeung ML, Deng W, Bao L, Jia L, et al. Treatment with lopinavir/ritonavir or interferon- $\beta 1 \mathrm{~b}$ improves outcome of MERS-CoV infection in a nonhuman primate model of common marmoset. J Infect Dis. (2015) 212:1904-13. doi: 10.1093/infdis/jiv392

73. Arabi YM, Alothman A, Balkhy HH, Al-Dawood A, AlJohani S, Al Harbi S, et al. Treatment of middle east respiratory syndrome with a combination of lopinavir-ritonavir and interferon- $\beta 1 \mathrm{~b}$ (MIRACLE trial): study protocol for a randomized controlled trial. Trials. (2018). 19:81. doi: 10.1186/s13063-017-2427-0
74. Sallard E, Lescure FX, Yazdanpanah Y, Mentre F, Peiffer-Smadja N. Type 1 interferons as a potential treatment against COVID-19. Antiviral Res. (2020) 178:104791. doi: 10.1016/j.antiviral.2020.104791

75. Zhang W, Zhao Y, Zhang F, Wang Q, Li T, Liu Z, et al. The use of antiinflammatory drugs in the treatment of people with severe coronavirus disease (2019). (COVID-19): the perspectives of clinical immunologists from China. Clin Immunol. (2020). 214:108393. doi: 10.1016/j.clim.2020.108393

76. Zhou Z, Ren L, Zhang L, Zhong J, Xiao Y, Jia Z, et al. Heightened innate immune responses in the respiratory tract of COVID-19 patients. Cell Host Microbe. (2020) 27:883-90.e2. doi: 10.1016/j.chom.2020.04.017

77. Korant BD, Kauer JC Butterworth BE. Zinc ions inhibit replicaction of rhinoviruses. Nature. (1974) 248:588-90. doi: 10.1038/248588a0

78. Cakman I, Kirchner H, Rink L. Zinc supplementation reconstitutes the production of interferon-alpha by leukocytes from elderly persons. $J$ Interferon Cytokine Res. (1997) 17:469-72. doi: 10.1089/jir.1997.17.469

79. Pisano $\mathrm{M}$, Hilas $\mathrm{O}$. Zinc and taste disturbances in older adults: a review of the literature. Consult Pharm. (2016) 31:267-70. doi: 10.4140/TCP.n.2016.267

80. Vaira LA, Salzano G, Deiana G, De Riu G. Anosmia and ageusia: common findings in COVID-19 patients. Laryngoscope. (2020) 130:1787. doi: 10.1002/lary.28692

81. Catalanotto FA, Nanda R. The effects of feeding a zinc-deficient diet on taste acuity and tongue epithelium in rats. J Oral Pathol. (1977) 6:21120. doi: 10.1111/j.1600-0714.1977.tb01643.x

82. McGonagle D, Sharif K, O'Regan A, Bridgewood C. The role of cytokines including Interleukin-6 in COVID-19 induced pneumonia and macrophage activation syndrome-like disease. Autoimmun Rev. (2020) 19:102537. doi: 10.1016/j.autrev.2020.102537

83. Mocchegiani E, Costarelli L, Giacconi R, Cipriano C, Muti E, Malavolta M. Zinc-binding proteins (metallothionein and alpha2 macroglobulin) and immunosenescence. Exp. Gerontol. (2006) 41:1094-107. doi: 10.1016/j.exger.2006.08.010

84. Liu MJ, Bao S, Napolitano JR, Burris DL, Yu L, Tridandapani S, et al. Zinc regulates the acute phase response and serum amyloid A production in response to sepsis through JAK-STAT3 signaling. PLoS ONE. (2014) 9:e94934. doi: 10.1371/journal.pone.0094934

85. Kahmann L, Uciechowski P, Warmuth S, Plumakers B, Gressner AM, Malavolta M, et al. Zinc supplementation in the elderly reduces spontaneous inflammatory cytokine release and restores $\mathrm{T}$ cell functions. Rejuvenation Res. (2008) 11:227-37. doi: 10.1089/rej.2007.0613

86. Licastro F, Grimaldi LM, Bonafè M, Martina C, Olivieri F, Cavallone L, et al. Interleukin- 6 gene alleles affect the risk of Alzheimer's disease and levels of the cytokine in blood and brain. Neurobiol Aging. (2003) 24:9216. doi: 10.1016/S0197-4580(03)00013-7

87. Testa R, Olivieri F, Bonfigli AR, Sirolla C, Boemi M, Marchegiani F, et al. Interleukin-6-174 G > C polymorphism affects the association between IL6 plasma levels and insulin resistance in type 2 diabetic patients. Diabetes Res Clin Pract. (2006) 71:299-305. doi: 10.1016/j.diabres.2005.07.007

88. Antonicelli R, Olivieri F, Bonafè M, Cavallone L, Spazzafumo L, Marchegiani F, et al. The interleukin-6-174 G $>$ C promoter polymorphism is associated with a higher risk of death after an acute coronary syndrome in male elderly patients. Int J Cardiol. (2005) 103:266-71. doi: 10.1016/j.ijcard.2004.08.064

89. Wong CP, Rinaldi NA, Ho E. Zinc deficiency enhanced inflammatory response by increasing immune cell activation and inducing IL6 promoter demethylation. Mol Nutr Food Res. (2015) 59:991-9. doi: 10.1002/mnfr.201400761

90. Giacconi R, Cipriano C, Albanese F, Boccoli G, Saba V, Olivieri F, et al. The $-174 \mathrm{G} / \mathrm{C}$ polymorphism of IL-6 is useful to screen old subjects at risk for atherosclerosis or to reach successful ageing. Exp Gerontol. (2004) 39:6218. doi: 10.1016/j.exger.2003.12.013

91. Mocchegiani E, Giacconi R, Costarelli L, Muti E, Cipriano C, Tesei S, et al. Zinc deficiency and IL-6-174G/C polymorphism in old people from different European countries: effect of zinc supplementation. ZINCAGE study. Exp Gerontol. (2008) 43:433-44. doi: 10.1016/j.exger.2008.01.001

92. https://www.worldometers.info/coronavirus/

93. von der Thüsen J, van der Eerden M. Histopathology and genetic susceptibility in COVID-19 pneumonia. Eur J Clin Invest. (2020) e13259. doi: $10.1111 /$ eci.13259 
94. Nguyen A, David JK, Maden SK, Wood MA, Weeder BR, Nellore A, et al. Human leukocyte antigen susceptibility map for severe acute respiratory syndrome Coronavirus 2. J Virol. (2020) 94:e00510-20. doi: 10.1128/JVI.00510-20

95. te Velthuis AJ, van den Worm SH, Sims AC, Baric RS, Snijder EJ, van Hemert MJ. $\mathrm{Zn}(2+)$ inhibits coronavirus and arterivirus RNA polymerase activity in vitro and zinc ionophores block the replication of these viruses in cell culture. PLoS Pathog. (2010) 6:e1001176. doi: 10.1371/journal.ppat.1001176

96. Xue J, Moyer A, Peng B, Wu J, Hannafon BN, Ding WQ. Chloroquine is a zinc ionophore. PLoS ONE. (2014) 9:e109180. doi: 10.1371/journal.pone.0 109180

97. Devaux CA, Rolain JM, Colson P, Raoult D. New insights on the antiviral effects of chloroquine against coronavirus: what to expect for COVID-19? Int J Antimicrob Agents. (2020) 55:105938. doi: 10.1016/j.ijantimicag.2020. 105938
98. Speth R, Carrera E, Jean-Baptiste, Joachim A, Linares A. Concentrationdependent effects of zinc on angiotensin-converting enzyme-2 activity (1067.4). FASEB J. (2014) 28(Suppl. 1):1067.

Conflict of Interest: The authors declare that the research was conducted in the absence of any commercial or financial relationships that could be construed as a potential conflict of interest.

Copyright (C) 2020 Mayor-Ibarguren, Busca-Arenzana and Robles-Marhuenda. This is an open-access article distributed under the terms of the Creative Commons Attribution License (CC BY). The use, distribution or reproduction in other forums is permitted, provided the original author(s) and the copyright owner(s) are credited and that the original publication in this journal is cited, in accordance with accepted academic practice. No use, distribution or reproduction is permitted which does not comply with these terms. 